\title{
Identification of distinct evolutionary units in allopatric populations of Hypostomus cf. wuchereri Günther, 1864 (Siluriformes: Loricariidae): karyotypic evidence
}

\author{
Jamille de Araújo Bitencourt ${ }^{1}$, Paulo Roberto Antunes de Mello Affonso ${ }^{2}$, \\ Lucia Giuliano-Caetano ${ }^{1}$ and Ana Lucia Dias ${ }^{1}$
}

Few chromosomal reports are available for the endemic fish fauna from coastal basins in northeastern Brazil, and regional biodiversity remains partially or completely unknown. This is particularly true for Loricariidae, the most diverse family of armored catfishes. In the present work, allopatric populations of Hypostomus $\mathrm{cf}$. wuchereri (Siluriformes: Loricariidae) from two basins in Bahia (northeastern Brazil) were cytogenetically analyzed. Both populations shared $2 \mathrm{n}=76$ chromosomes, a karyotype formula of $10 \mathrm{~m}+18 \mathrm{sm}+48 \mathrm{st} / \mathrm{a}(\mathrm{FN}=104)$ and single terminal GC-rich NORs on the second metacentric pair. Nevertheless, microstructural differences were detected by C-banding, fluorochrome staining and chromosomal digestion with restriction enzymes (Alu I, Bam HI, Hae III, and Dde I). The population from Una River (Recôncavo Sul basin) showed conspicuous heterochromatin blocks and a remarkable heterogeneity of base composition (presence of interspersed AT/GC-rich and exclusively AT- or GC-rich sites), while the population from Mutum river (Contas River basin) presented interstitial AT-rich Cbands and terminal GC/AT-rich heterochromatin. Each enzyme yielded a specific band profile per population which allowed us characterizing up to five heterochromatin families in each population. Based on the present data, we infer that these populations have been evolving independently, as favored by their geographic isolation, probably representing cryptic species.

Poucos dados cromossômicos estão disponíveis para a fauna de peixes endêmicos das bacias costeiras do nordeste do Brasil, e a biodiversidade regional continua a ser parcial ou completamente desconhecida. Isto é particularmente verdadeiro para Loricariidae, a mais diversa família de cascudos. No presente trabalho, populações alopátricas de Hypostomus cf. wuchereri (Siluriformes: Loricariidae) de duas bacias hidrográficas da Bahia (nordeste do Brasil) foram citogeneticamente analisadas. Ambas as populações compartilham $2 \mathrm{n}=76$ cromossomos, uma fórmula cariotípica de $10 \mathrm{~m}+18 \mathrm{sm}+48 \mathrm{st} / \mathrm{a}(\mathrm{FN}=104)$ e um único sinal terminal de RONs GC-ricas no segundo par metacêntrico. No entanto, diferenças microestruturais foram detectados pelo bandeamento C, coloração com fluorocromos e digestão cromossômica com enzimas de restrição ( $A l u$ I, BamH I, Hae III e Dde I). A população do rio Una (bacia do Recôncavo Sul) apresentou blocos de heterocromatina conspícuos e grande heterogeneidade de composição de base (presença de sítios AT/GC-ricos intercalados e exclusivamente AT ou GC-ricos), enquanto a população do rio Mutum (bacia do Rio de Contas) apresentou bandas C intersticiais AT-ricas e heterocromatina terminal GC/AT-ricas. Cada enzima gerou um perfil específico de bandas por população que nos permitiu caracterizar até cinco famílias de heterocromatina em cada população. Baseado nos presentes dados, podemos inferir que essas populações têm evoluido de forma independente, favorecidas pelo seu isolamento geográfico, provavelmente representando espécies crípticas.

Key words: Biodiversity, Cytogenetics, Heterochromatin, Hypostominii.

\footnotetext{
1'Departamento de Biologia Geral, Universidade Estadual de Londrina, CCB. 86051-970 Londrina, Paraná, Brazil. millebitencourt@gmail.com, giuliano@uel.br,anadias@uel.br

${ }^{2}$ Departamento de Ciências Biológicas, Universidade Estadual do Sudoeste da Bahia, DCB. 45200-000 Jequié, Bahia, Brazil. paulomelloaffonso@yahoo.com.br
} 


\section{Introduction}

The ichthyofauna from coastal hydrographic systems in Eastern Brazil presents a remarkable biogeographic significance. The main basins in this region (Paraguaçu, Contas, Jequitinhonha, Doce, Paraíba do Sul, Ribeira de Iguape, Itajaí, and Jacuí ) as well as several other small drainages show high rates of endemism (Ribeiro et al., 2006). In fact, the number of recently described or reevaluated species is getting higher and higher as long as taxonomic analyses focusing on these basins increase, confirming the richness of regional and often threatened new species (Sarmento-Soares et al., 2009; Zanata \& Camelier 2009; Cetra et al., 2010).

On the other hand, biodiversity studies depend on information about intra and interpopulation variability levels and characterization of evolutionarily significant units. In this sense, cytogenetic analyses represent a useful tool for conservation genetics, mainly of taxonomically controversial groups, once they can reveal population polymorphisms, discriminate cryptic species and cannot be replaced by DNA studies (Allendorf \& Luikart, 2007). However, in spite of the great number of chromosomal reports in fishes from South and Southeastern Brazil and, more recently, from Amazon basin, little is known about the cytogenetic features of species from Northeastern region (Medrado et al., 2008; Jacobina et al., 2009).

Hypostomus is one of the most species-rich genera within the order Siluriformes, encompassing from 117 to 130 species. Such imprecise species number is because Aphanotorulus, Isorineloricaria, and Squaliforma are recognized as valid genera by Ferraris Jr. (2007), while Armbruster $(2004,2007)$ refer to them as a synonym for Hypostomus. Ever since, new species have been continuously described, reinforcing the remarkable diversity of forms in this genus, which composes a dominant fish group in virtually all Brazilian rivers (Jerep et al., 2007; Zawadski et al., 2008).

The species Hypostoms wuchereri was identified by Günther in 1864 from "rivers of Brazil". Although the type locality is undefined, it is thought that the author actually referred to Paraguaçu River basin, in Bahia, Northeastern Brazil (Reis et al., 2003). Nonetheless, the lack of more detailed inventories hinders the definition of its real distribution, so far being restricted to reports from Paraguaçu and São Francisco basins (cited as Hypostomus cf. wuchereri by Garavello \& Garavello, 2004).

Therefore, the goal of the present work was to analyze cytogenetically two populations of Hypostomus $\mathrm{cf}$. wuchereri from closely related coastal basins in Bahia, Brazil (Contas and Recôncavo Sul), providing new insights about the diversity and evolution of the regional ichthyofauna and biogeographic and evolutionary studies in the region.

\section{Material and Methods}

Thirteen specimens ( 7 males, 1 female and 5 immature juveniles) of Hypostomus cf. wuchereri were collected in Mutum River (1343'18”S 3951'20”'W), Contas River basin,
Municipality of Jequié, and six individuals (1 male and five

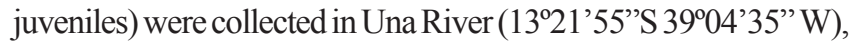
Recôncavo Sul basin, Municipality of Valença, both in Bahia State, Northeastern Brazil. Voucher specimens were identified by Claudio Zawadzki (Universidade Estadual de MaringáUEM) and deposited in the icthyological collection at NUPELIA -UEM, Maringá, PR, Brazil (NUP 9813).

Mitotic chromosomes were obtained according to Bertollo et al. (1978). The mitotic stimulation followed the procedure described by Molina (2001) using a commercial bacterial and fungal antigen (Munolan $\left.{ }^{\circledR}\right)$. The cells were dropped onto glass slides, air dried and stained with Giemsa at 5\% for conventional analyses.

The nucleolus organizer regions were detected by silver nitrate staining - AgNORs (Howell \& Black, 1980). The pattern of heterochromatin distribution was determined by C-banding (Sumner, 1972). The GC- and AT-rich sites were visualized by sequential fluorochrome staining, using distamycin, chromomycin $\mathrm{A}_{3}\left(\mathrm{CMA}_{3}\right)$ and 4'-6-diamidino-2-phenylindole (DAPI), respectively (Schweizer, 1980). The in situ digestion with restriction endonucleases was performed according to Mezzanotte et al. (1983), using the following enzymes Alu I (5'-AG CT - 3') at $0.4 \mathrm{U} / \mu \mathrm{l}$ for $4 \mathrm{~h}, \mathrm{Bam} \mathrm{HI}\left(5^{\prime}\right.$ - G GATCC - 3') at $0.5 \mathrm{U} / \mu \mathrm{l}$ for $15 \mathrm{~h}, \mathrm{Hae} \mathrm{III}\left(5^{\prime}-\mathrm{GG} \mathrm{CC}-3^{\prime}\right)$ at $0.6 \mathrm{U} / \mu \mathrm{l}$ for $14 \mathrm{~h}$, and Dde I (5'- C TNAG - 3') at $2 \mathrm{U} / \mu \mathrm{l}$ for $4 \mathrm{~h}$. An ideogram representing the karyotype and showing the digestion pattern of heterochromatic regions was constructed using the software EasyIdio v. 3.0 (Diniz \& Xavier, 2006), based on the pair measurements and chromosomal bands.

The metaphase spreads were analyzed in a photomicroscope Olympus BX51 and the best spreads were digitalized using the software Image-Pro ${ }^{\circledR}$ Plus v. 6.2 (Media Cybernetics). Based on the arm ratio, the chromosomes were classified into: metacentric (m), submetacentric (sm), subtelocentric (st) and acrocentric (a), according Levan et al. (1964). The fundamental numbers of arms (FN) was estimated taking into account that $\mathrm{m} / \mathrm{sm}$ chromosomes are bi-armed and st/a elements are one-armed.

\section{Results}

All specimens of Hypostomus cf. wuchereri shared a modal number of $2 \mathrm{n}=76$, with a karyotype formula of $10 \mathrm{~m}+18 \mathrm{sm}+48 \mathrm{st} / \mathrm{a}(\mathrm{FN}=104)$ independently on the population (Fig. 1).

Silver nitrate staining revealed single NORs located at terminal regions on long arms of the second metacentric pair in both populations (Fig. 1, detail). Usually, the NOR size was heteromorphic between homologous and coincident to secondary constrictions.

On contrary, the heterochromatin distribution differed between populations. The specimens from Mutum River showed more conspicuous C-bands at terminal portions of a submetacentric pair $\left(8^{\text {th }}\right)$ and three acrocentric pairs $\left(21^{\text {st }}, 26^{\text {th }}\right.$, and $29^{\text {th }}$ ) besides the interstitial region of four acrocentric pairs $\left(16^{\text {th }}, 18^{\text {th }}, 28^{\text {th }}\right.$, and $\left.31^{\text {st }}\right)$ (Fig. 2). The sample from Una 



Fig. 1. Karyotypes of Hypostomus cf. wuchereri. (a) population from Mutum River, (b) population from Una River. In detail, the NOR-bearing pair after silver nitrate (Ag-NOR) and C-banding (CB).

River presented five pair of acrocentric chromosomes $\left(17^{\text {th }}\right.$, $21^{\text {st }}, 24^{\text {th }}, 26^{\text {th }}$, and $31^{\text {st }}$ ) bearing large terminal blocks and an acrocentric pair $\left(30^{\text {th }}\right)$ with a subtle interstitial C-band (Fig. 3). Centromeric and NOR-associated heterochromatin was not identified in the studied populations (Figs. 1-2-3).

After enzyme digestion, the population from Mutum River presented distinct heterochromatin types, divided into five groups: the heterochromatic block from pair 8 was digested by all tested enzymes; C-bands from pairs 18, 21, and 28 were digested by Alu I, Dde I, and Bam HI; those from pairs 16 and 31 were digested by Bam $\mathrm{HI}$; the heterochromatin from pair 26 was digested by Alu I and Bam HI; and the heterochromatic segment from pair 29 remained undigested, independently on the enzyme (Table 1, Fig. 2).

The specimens from Una River revealed three heterochromatin classes after enzyme digestion: the C-bands from pairs 26,30 , and 31 were digested by all enzymes; that from pair 24 and the terminal portion of the heterochromatic block in a chromosome from pair 17 were digested by Dde I; the $\mathrm{C}$-band from pair 21 and the central region of the heterochromatic block in a chromosome from pair 17 were digested by Dde I and Bam HI (Table 1, Fig. 3).

As for the euchromatic regions, the population from Mutum River, the enzymes Hae III and Dde I resulted in a 


\begin{tabular}{|c|c|c|c|c|c|c|c|c|}
\hline Pair & 8 & 16 & 18 & 21 & 26 & 28 & 29 & 31 \\
\hline C-banding & & & & & & 슬 스 & A. & 스. \\
\hline Alu $\mathrm{I}$ & & & & & & A & & 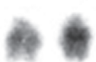 \\
\hline Hae III & & & & & & 를 & 츨 & 추 \\
\hline Dde I & & & & & & 焉害 & 18 & 86 \\
\hline Bam HI & & & & & t6 6 & Sำ & d $\mathrm{t}$ & $6 \mathrm{~A}$ \\
\hline
\end{tabular}

Fig. 2. Chromosomal pairs of Hypostomus cf. wuchereri from Mutum River showing the C-bands and the digestion profiles using Alu I, Hae III, Dde I, and Bam HI.

\begin{tabular}{|c|c|c|c|c|c|c|}
\hline Pair & 17 & 21 & 24 & 26 & 30 & 31 \\
\hline C-banding & & & & & & \\
\hline Alu I & & & & & & \\
\hline Hae III & & & & & & \\
\hline Dde I & & & & & & \\
\hline Bam HI & & & & & s. & \\
\hline
\end{tabular}

Fig. 3. Chromosomal pairs of Hypostomus cf. wuchereri from Una River showing the C-bands and the digestion profiles using Alu I, Hae III, Dde I, and Bam HI.

large amount of bands throughout chromosomes while the target sequence of Alu I has proved to be homogeneously spread through genome. In the population from Una River, the target sequences of both Hae III and Dde I were uniformly distributed through euchromatin but Alu I yielded a banding profile. The digestion using $\mathrm{Bam} \mathrm{HI}$ revealed no differences between both populations (data nor shown).

Both populations were also distinguished according to base-specific fluorochrome staining. The specimens from Mutum River presented AT-rich sites (DAPI ${ }^{+}$) in the interstitial heterochromatin detected by C-banding from pairs 16, 18, 21, 28,29 , and 31 . On the other hand, the terminal heterochromatic blocks from pair 16 presented interspersed $\mathrm{CMA}_{3}$ and DAPI staining (Fig. 4a). The population from Una River presented $\mathrm{CMA}_{3}{ }^{+}$and $\mathrm{DAPI}^{+}$interspersed blocks in the heterochromatin of pairs 17,21,24, and 31 , besides exclusively AT-rich segments (pairs 20, 25, 28, 34, and 35) and GC-rich sites (pair 29), revealing a remarkable heterogeneity in base composition (Fig. 4b).

\section{Discussion}

A high diploid number with several acrocentric chromosomes, as reported for $H$. cf. wuchereri, can be regarded as a derived feature within this genus once $2 \mathrm{n}=54 / \mathrm{FN}=108$ seems to represent the plesiomorphic condition for Loricariidae (Artoni \& Bertollo, 2001). Based on this assumption, centric fissions should have played a major role in the karyotype evolution of $H$. cf. wuchereri, thereby increasing the basal diploid values and the number of onearmed chromosomes. A similar situation is observed in other 
Table 1. Results of enzymatic digestion of C-bands in chromosomal pairs of Hypostomus cf. wuchereri, using the restriction endonucleases Alu I, Hae III, Dde I, and Bam HI. $(+)=$ digested heterocrchromatin; $(-)=$ undigested heterochromatin; $( \pm)=$ partially digested heterochromatin

\begin{tabular}{cccccc}
\hline & C-band & \multicolumn{3}{c}{ Restriction Enzyme } \\
Population & Pair & Alu I Hae III & Dde I Bam HI \\
\hline & 8 & + & + & + & + \\
& 16 & - & - & - & + \\
Mutum River (Contas River basin) & 18 & + & - & + & + \\
& 21 & + & - & + & + \\
& 26 & + & - & - & + \\
& 28 & + & - & + & + \\
& 29 & - & - & - & - \\
& 31 & - & - & - & + \\
\hline & 17 & - & - & + & + \\
Una River (Recôncavo Sul basin) & 21 & - & - & + & + \\
& 24 & - & - & + & - \\
& 26 & + & + & + & + \\
& 30 & + & + & + & + \\
& 31 & + & + & + & + \\
\hline
\end{tabular}

congeneric species, showing that, in spite of their wide chromosomal variation ( $2 n=54$ to $2 n=84$ ), $2 n=76$ is the most frequent condition in Hypostomus, being observed in $25.8 \%$ of analyzed species (Bitencourt, 2010).

The nucleolar organizer regions (NORs) are also variable in both number and position in Hypostomus. In the case of the studied species, the presence of single NORs diverges from the common pattern in Hypostomus and points towards the maintenance of the plesiomorphic condition in Loricariidae and fishes in general (Artoni \& Bertollo, 2001). Nonetheless, similarly to the great majority of cytogenetic reports in this genus, the NOR size was usually heteromorphic between homologous in $H$. cf. wuchereri (Fig.1, detail). Such polymorphism is frequently reported in species bearing single NORs and are thought to result from duplications/deletions or unequal crossovers, as hypothesized by several authors (Galetti, 1998; Affonso et al., 2002).

Heterochromatin analysis was particularly efficient to compare the chromosomal structure of the studied populations. Specimens from Mutum River presented some chromosomes with interstitial heterochromatin and less evident C-bands while $H$. cf. wuchereri from Una River presented conspicuous terminal C-bands (Fig. 2-3). Artoni \& Bertollo (2001) showed that some species of the tribe Hypostominii with high diploid numbers usually bear interstitial heterochromatic segments over several acrocentric chromosomes and, inversely, species with low $2 \mathrm{n}$ values carry small amounts of heterochromatin located at either terminal or centromeric regions. However, the C-banding pattern observed in $H$. cf. wuchereri (high diploid number) suggests that the heterochromatin distribution within Hypostominae is more diversified than previously thought.

The differentiated location of heterochromatic blocks in the studied species might be derived from inversions and/or transposition of originally terminal heterochromatin of some acrocentric chromosomes to interstitial position or viceversa, following the non-random chromosomal arrangement during interphase (Schweizer \& Loidl, 1987; Bitencourt, 2010). This behavior would explain the equilocal distribution of heterochromatin between non-homologous chromosomes in the population from Mutum River, as also proposed for Hypostomus sp. E and Hypostomus sp. F by Artoni \& Bertollo (1999).

It should be pointed out that the population from Mutum River is morphologically and cytogenetically similar to specimens of Hypostomus aff. unae from Preto do Criciúma River, within the same subbasin (Bitencourt, 2010). Nonetheless, the presence of two chromosomal pairs bearing conspicuous heterochromatic blocks in the population of $H$. cf. wuchereri (pairs 21 and 26) allows differentiating both species, reinforcing the relevance of chromosomal bandings in the characterization of specific markers.

Besides facilitating the chromosomal pairing, the in situ digestion with four restriction endonucleases (Alu I, Hae III, Bam HI, and Dde I) also revealed different families of repetitive DNA. The weakly stained regions correspond to heterochromatin loss caused by enzyme digestion whereas conspicuous bands indicate undigested regions lacking target sequences and/or presenting differential chromatin conformation and protein associations (Gosálvez et al., 1987; Burkholder \& Weaver, 1977).

The chromosomal treatment using the selected restriction enzymes yielded a remarkable heterogeneity between both populations of Hypostomus cf. wuchereri, indicating that they carry heterochromatin families composed of distinct highly repetitive DNA sequences. A few similarities were observed between the studied populations like the heterochromatin of pairs 26, 30, and 31 from the Una River sample and the pair 8 from Mutum River specimens, which were digested by all enzymes (Fig. 5).

Another peculiarity in the enzymatic digestion observed in $H$. cf. wuchereri from Una River refers to the heteromorphic bands between homologous chromosomes of the $17^{\text {th }}$ pair after using Bam HI, which digested only the central portion of the heterochromatic blocks of one homologous (Fig. 3). This result reveals the remarkable heterochromatin heterogeneity between the analyzed populations. Moreover, differences in euchromatin regions were also detected, mainly using Hae III, Dde I, and Alu I (data not shown).

A contradictory situation was observed in relation to the activity of Hae III. Since this enzyme acts over GC repeats, it was expected that the GC-rich heterochromatin $\left(\mathrm{CMA}_{3}^{+}\right)$from pairs 17, 21, and 24 in Una River samples would be digested but they remained intact (Figs. 3-4b). Gosálvez et al. (1987) stated that the effects of enzymatic digestion on chromosomes are explained either by the presence/absence of target sequences or by their ability in assessing these sequences what can be hindered by chromatin configuration or by the small size of specific targets. In this sense, it is possible that these constraints have been responsible for the non-digestion of such heterochromatic blocks by Hae III.

The available reports show that GC-rich regions are 


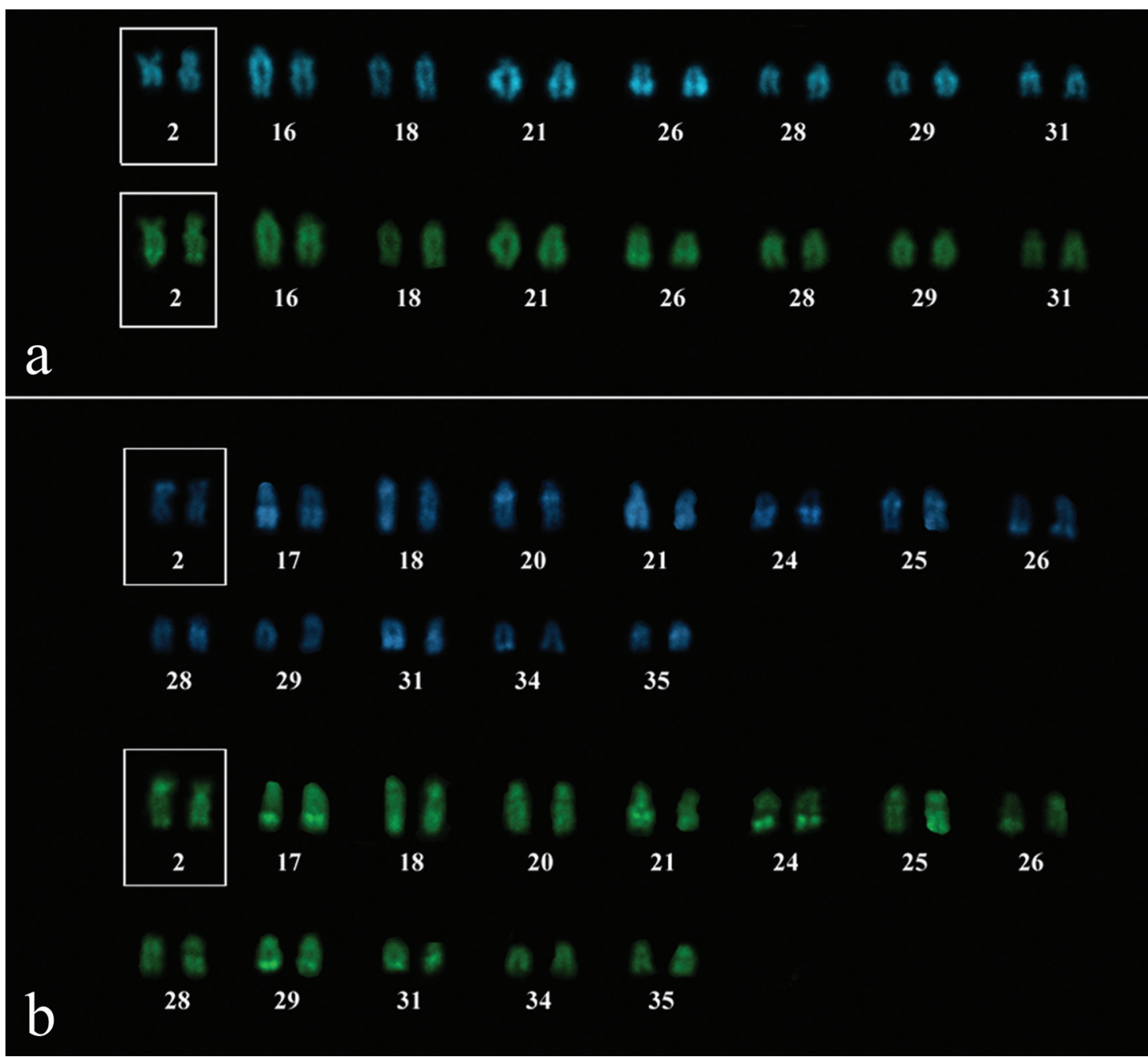

Fig. 4. DAPI and $\mathrm{CMA}_{3}$ stained chromosomal pairs from Mutum (a) and Una (b) Rivers, showing AT and GC-rich sites, respectively. The NOR-bearing pair is highlighted.

widespread in Hypostomus and, although rare in fish, DAPI ${ }^{+}$ signals are also identified in some species of this genus (Artoni et al., 1998; Artoni \& Bertollo, 1999; Kavalco et al., 2004). Usually, NORs in Hypostomus are $\mathrm{CMA}_{3}^{+}$, as observed in three populations of $H$. nigromaculatus (Rubert et al., 2008), Hypostomus sp. 2 - rio Perdido NUP 4249 (Cereali et al., 2008) and in the present study.

On the other hand, the interstitial AT-rich segments in the population from Mutum River are located in equivalent regions of distinct chromosomal pairs which, most likely, were distributed to equilocal sites by specific models of heterochromatin dispersion within a morphological class such as acrocentrics (Schweizer \& Loidl, 1987; Artoni \& Bertollo, 1999; Affonso \& Galetti, 2005). In the case of specimens from Una River, the heterochromatin seems to have undergone a unique evolutionary pathway once interspersed AT- and GCrich regions are present in several chromosomes, a unusual condition in lower vertebrates. The origin of this pattern is unclear but it might putatively be determined by the insertion of GC-rich segments into formerly AT-rich heterochromatin. Once established, this heterogeneous sequence could be dispersed to equidistant regions over several chromosomal pairs, as previously described in other fish species (Mantovani et al., 2000). In Hypostomus, a similar mechanism of heterochromatin dispersal has been suggested among nonhomologous chromosomes based on their distribution in the nucleus, resulting in concert evolution of this heterochromatin class (Artoni \& Bertollo, 1999).

The remarkable microstructural differentiation amongst the studied samples of $H$. cf. wuchereri is likely to reflect their unique evolutionary pathways, giving rise to distinctive families of repetitive DNA. Such divergence would be favored by the geographical isolation between both basins and fixed in each population by differential selective pressures or else drift effects. These data are in accordance with previous available reports, such as distribution ranges of some fish groups and identification of endemic species, indicating the occurrence of biogeographic units and/or subprovinces 


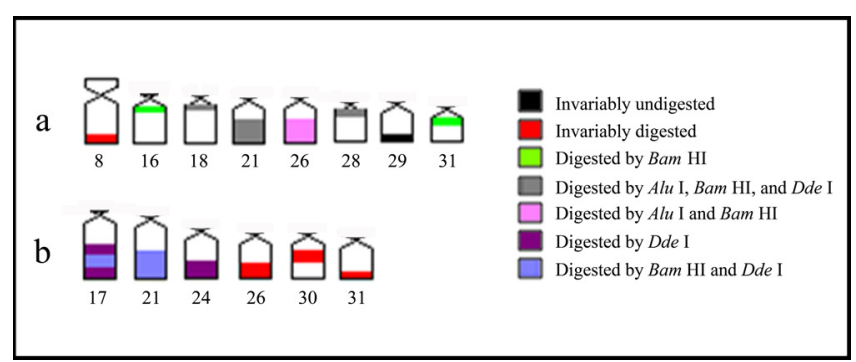

Fig. 5. Representative ideogram of chromosomal pairs in Hypostomus cf. wuchereri showing the banding pattern after digestion using Alu I, Bam HI, Hae III, and Dde I. (a) population from Una River, (b) population from Mutum River.

throughout eastern Brazilian coastal basins that should be considered prior implementation or expansion of conservation units (Ribeiro, 2006; Cetra et al., 2010).

Actually, multiple and successive events of shortening and expansion on tectonic plates have affected the continental margin of Brazil and might have favored either the splitting or connectivity among adjacent drainages (Lundberg et al., 1998; Pamponet et al., 2008). Hypothetically, the last marine transgression over the continent could have separated formerly connected coastal populations, thereby promoting allopatric diversification (Beheregaray et al., 2002). A similar evolutionary scenario was observed in Hoplias malabaricus (Characiformes: Erythrinidae), in which differential heterochromatin contents indicated a genetic separation between two coastal basins in Bahia State (Jacobina et al., 2009).

Although the role of heterochromatin in speciation is controversial once it seems not to affect fertility (King, 1987), some authors propose that heterochromatin changes might lead to diversification in certain animal groups (Pathak et al., 1973; Hamilton et al., 1992; Hatanaka et al., 1998). Recently, Molina et al. (2008) showed that different C-banding patterns in a single chromosomal pair were related to a set of morphological traits and population structure in Leporinus elongatus (Characiformes: Anostomidae), indicating that heterochromatin can be associated with phenotypic differentiation.

Analogously, we can infer that $H$. cf. wuchereri populations have been evolving independently in each basin and are likely to represent cryptic forms in which the distinctive heterochromatic blocks in several chromosomes from each population reinforce their degree of isolation.

\section{Acknowledgements}

The authors would like to thank Cláudio Henrique Zawadzki (UEM-NUPELIA) for specimens' identification, Ana Maria Waldschmidt (UESB) for providing part of the material used in the present research and Conselho Nacional de Desenvolvimento Científico e Tecnológico ( $\mathrm{CNPq})$ for the financial support.

\section{Literature Cited}

Affonso, P. R. A. M. \& P. M. Galetti Jr. 2005. Chromosomal diversification of reef fishes from genus Centropyge (Perciformes, Pomacanthidae). Genetica, 123: 227-233.

Affonso, P. R. A. M., W. Guedes, E. Pauls \& P. M. Galetti Jr. 2002. Close karyotypical relationship between two species of marine angelfishes from South Atlantic: Pomacanthus arcuatus and $P$. paru (Perciformes, Pomacanthidae). Caryologia, 55: 323-329.

Allendorf, F. R. \& G. Luikart. 2007. Conservation and the genetics of populations. Oxford, Blackwell Publishing, 642p.

Armbruster, J. W. 2004. Phylogenetic relationships of the suckermouth armoured catfishes (Loricariidae) with emphasis en teh Hypostominae and the Ancistrinae. Zoological Journal of the Linnean Society, 141: 1-80.

Armbruster, J. W., L. A. Tansey \& N. K. Lujan. 2007. Hypostomus rhantos (Siluriformes: Loricariidae), a new species from southern. Zootaxa, 1553: 59-68.

Artoni, R. F. \& L. A. C. Bertollo. 1999. Nature and distribution of constitutive heterochromatin in fishes, genus Hypostomus (Loricariidae). Genetica, 106: 209-214.

Artoni, R. F. \& L. A. C. Bertollo. 2001. Trends in the karyotype evolution of Loricariidae fish (Siluriformes). Hereditas, 134: 201-210.

Artoni, R. F., P. C. Venere \& L. A. C. Bertollo. 1998. A heteromorphic ZZ/ZW sex chromosome system in fish, genus Hypostomus (Loricariidae). Cytologia, 63:421-425.

Beheregaray, L. B., P. Sunnucks \& D. A. Briscoe. 2002. A rapid fish radiation associated with the last sea level changes in southern Brazil: the silverside Odontesthes perugiae complex. Proceedings of the Royal Society London Series B, 269: 65-73.

Bertollo, L. A. C., G. G. Born, J. Dergam, A. S. Fenocchio \& O. Moreira-Filho. 2000. A biodiversity approach in the neotropical Erythrinidae fish, Hoplias malabaricus. Karyotypic survey, geographic distribution of cytotypes and cytotaxonomic considerations. Chromosome Research, 8: 603-613.

Bertollo, L. A. C., C. S. Takahashi \& O. Moreira-Filho. 1978. Cytotaxonomic considerations on Hoplias lacerdae (Pisces, Erythrinidae). Brazilian Journal of Genetics, 1:103-120.

Bitencourt, J. A. 2010. Análise citogenética de espécies do gênero Hypostomus (Loricariidae: Hypostominae) das bacias do rio de Contas e Recôncavo Sul/Bahia. Unpublished Ph.D. Dissertation, Universidade Estadual de Londrina, Londrina, 99p.

Burkholder, G. D. \& M. G. Weaver. 1977. DNA-protein interactions and chromosome banding. Experimental Cell Research, 110: 251262.

Cereali, S. S., E. Pomini, R. Rosa, C. H. Zawadzki, O. Froehlich \& L. Giuliano-Caetano. 2008. Karyotype description of two species of Hypostomus (Siluriformes, Loricariidae) of the Planalto da Bodoquena, Brazil. Genetics and Molecular Research, 7: 583-591.

Cetra, M., L. M. Sarmento-Soares, R. F. Martins-Pinheiro. 2010. Peixes de riachos e novas Unidades de Conservação no sul da Bahia. Pan-American Journal of Aquatic Sciences, 5: 11-21.

Diniz, D. \& P. M. Xavier. 2006. Easy Idio. Available from: http:// geocities.yahoo.com.br/easyidio/ (October 12, 2009).

Ferraris Jr., C. J. 2007. Checklist of catfishes, recent and fossil (Osteichthyes: Siluriformes), and catalogue of siluriform primary types. New Zealand, Magnolia Press, 628p.

Galetti Jr., P. M. 1998. Chromosome diversity in neotropical fishes: NOR studies. Italian Journal of Zoology, 65: 53-56. 
Garavello, J. C. \& J. P. Garavello. 2004. Spatial distribution and interaction of four species of the catfish genus Hypostomus lacépède with bottom of rio São Francisco, canindé do São Francisco, Sergipe, Brazil (Pisces, Loricariidae, Hypostominae). Brazilian Journal of Biology, 64: 591-598.

Gosálvez, J., J. L. Bella, C. López-Fernández \& R. Mezzanottet. 1987. Correlation between constitutive heterochromatin and restriction enzyme resistant chromatin in Arcyptera tornosi (Orthoptera). Heredity, 59: 173-180.

Hamilton, M. J., G. Hong \& H. A. Wichman. 1992. Intragenomic movement and concerted evolution of satellite DNA in Peromyscus: evidence from in situ hybridization. Cytogenetics and Cell Genetics, 60: 40-44.

Hatanaka, T., A. J. Tambasco \& P. M. Galetti Jr. 1998. Heterochromatin heterogeneity and chromosome heteromorphism in Cerdocyon thous (Mammalia, Canidae). Genetics and Molecular Biology, 21: 227-231.

Howell, W. M. \& D. A. Black. 1980. Controlled silver staining of nucleolus organizer regions with a protective colloidal developer: a 1-step method. Experientia, 36: 1014-1015.

Jacobina, U., P. R. A. M. Affonso, P. L. S. Carneiro \& J. A. Dergam. 2009. Biogeography and comparative cytogenetics between two populations of Hoplias malabaricus (Bloch, 1794) (Ostariophysi, Erythrinidae) from coastal basins in the State of Bahia, Brazil. Neotropical Ichthyology, 7: 617-622.

Jerep, F. C., O. A. Shibatta \& C. H. Zawadzki. 2007. A new species of Hypostomus Lacépède, 1803 (Siluriformes: Loricariidae) from the upper rio Paraná basin, Southern Brazil. Neotropical Ichthyology, 5: 435-442.

Kavalco, K. F., R. Pazza, L. A. C. Bertollo \& O. Moreira-Filho. 2004. Heterochromatin characterization of four fish species of the family Loricariidae (Siluriformes). Hereditas, 141: 237-242.

King, M. 1987. Chromosomal rearrangements, speciation and the theoretical approach. Heredity, 59: 1-6.

Lundberg, J. G., L. G. Marshall, J. Guerrero, B. Horton, M. C. S. L. Malabarba \& F. Wesselingh. 1998. The stage for neotropical fish diversification: A history of tropical South America rivers. Pp. 13-48. In: Malabarba, L. R., R. E. Reis, R. P. Vari, Z. M. S. Lucena \& C. A. S. Lucena (Eds.). Phylogeny and Classification of Neotropical Fishes, Porto Alegre, Edipucrs, 603p.

Mantovani, M., L. D. S. Abel, C. A. Mestriner \& O. Moreira-Filho. 2000. Accentuated polymorphism of heterochromatin and nucleolar organizer regions in Astyanax scabripinnis (Pisces, Characidae): tools for understanding karyotypic evolution. Genetica, 109: 161-168.

Medrado, A. S., A. V. A. Figueiredo, A. M. Waldschimidt, P. R. A. M. Affonso \& P. L. S. Carneiro. 2008. Cytogenetic and morphological diversity in populations of Astyanax fasciatus (Teleostei, Characidae) from Brazilian northeastern river basins. Genetics and Molecular Biology, 31: 208-214.
Mezzanotte, R., U. Bianchi, R. Vanni \& L. Ferruci. 1983. Chromatin organization and restriction nuclease activity on human methaphase chromosomes. Cytogenetics and Cell Genetics, 36: 562-566.

Molina, W. F. 2001. An alternative method for mitotic stimulation in fish cytogenetics. Chromosome Science, 5: 149-152.

Molina, W. F., O. Shibatta, P. M. Galetti Jr. 2008. Chromosomal evidence of population subdivision in the freshwater fish Leporinus elongatus in the Upper Paraná River basin. Genetics and Molecular Biology, 31: 270-274.

Pamponet, V. C. C., P. L. S. Carneiro, P. R. A. M. Affonso, V. S. Miranda, J. C. Silva Junior, C. G. Oliveira \& F. A. Gaiotto. 2008. A multi-approach analysis of the genetic diversity in populations of Astyanax aff. bimaculatus Linnaeus, 1758 (Teleostei, Characidae) from Northeastern Brazil. Neotropical Ichthyology, 6: 621-630.

Pathak, S., T. C. Hsu \& F. E. Arrighi. 1973. Chromosomes of Peromyscus (Rodentia, Cricetidae) IV. The role of heterochromatin in karyotypic evolution. Cytogenetics and Cell Genetics, 12: 315-326.

Reis, R. E., S. O. Kullander \& J. R. Ferraris Jr. 2003. Checklist of the freshwater fishes of Sonth and Central América. Porto Alegre, Edipucrs, 729p.

Ribeiro, A. C. 2006. Tectonic history and the biogeography of the freshwater fishes from the coastal drainages of eastern Brazil: an example of faunal evolution associated with a divergent continental margin. Neotropical Ichthyology, 4: 225-246.

Rubert, M., C. H. Zawadzki \& L. Giuliano-Caetano. 2008. Cytogenetic characterization of Hypostomus nigromaculatus (Siluriformes: Loricariidae). Neotropical Ichthyology, 6: 93-100.

Sarmento-Soares, L. M., P. Lehmann \& R. F. Martins-Pinheiro. 2009. Parotocinclus arandai, a new species of Hypoptopomatinae catfish (Siluriformes: Loricariidae) from the upper rios Jucuruçu and Buranhém, States of Bahia and Minas Gerais, Brazil. Neotropical Ichthyology, 7: 191-198.

Schweizer, D. 1980. Simultaneous fluorescent staining of R bands and specific heterocromatic regions (DA/DAPI) in human chromosomes. Cytogenetics and Cell Genetics, 27: 190-193.

Schweizer, D. \& J. Loidl. 1987. A model for heterochromatin dispersion and the evolution of C-bands patterns. Chromosomes Today, 9: 61-74.

Sumner, A. T. 1972. A simple technique for demonstrating centromeric heterochromatin. Experimental Cell Research, 75: 304-306.

Zanata, A. \& P. Camelier. 2009. Astyanax vermilion and Astyanax burgerai: new characid fishes (Ostariophysi: Characiformes) from Northeastern Bahia, Brazil. Neotropical Ichthyology, 7: 175-184.

Zawadzki, C. H., C. Weber \& C. S. Pavanelli. 2008. Two new species of Hypostomus Lacépède (Teleostei: Loricariidae) from the upper rio Paraná basin, Central Brazil. Neotropical Ichthyology, 6: 403-412. 